\title{
Notes
}

\section{Rationalizing Antitrust Cluster Markets}

\author{
Ian Ayres $\dagger$
}

Courts have traditionally defined antitrust markets on the basis of substitutability. ${ }^{1}$ Several antitrust decisions involving multiproduct defendants, however, have departed from this standard and defined "clusters" of non-substituting and untied ${ }^{2}$ products to be the relevant line of commerce. $^{3}$ The use of such cluster definitions has preceded the development

$†$ I would like to thank Peter Ezersky, Al Klevorick and Richard Schmalensee for helpful comments. Special thanks go to Thomas Welch for piquing my interest in this subject and to Walter Vandaele for encouraging my research.

1. The courts' objective in defining the relevant line of commerce for antitrust purposes has been "to recognize competition where, in fact, competition exists." Brown Shoe Co. v. United States, 370 U.S. 294, 326 (1962). Because substitutes compete, substitutability in demand or supply has been the prime criterion for setting the boundaries of a market. United States v. E.I. du Pont de Nemours \& Co., 351 U.S. 377, 395 (1956) (goods that are "reasonably interchangeable by consumers" should be placed in the same market); Brown Shoe Co., 370 U.S. at $325 \mathrm{n} .42$ ("cross-elasticity of production facilities may also be an important factor in defining a product market"). By this substitutability criterion, if an antitrust defendant produced several goods (that is, was a multiproduct firm), a separate market would be defined for each of the defendant's products, consisting of each product's respective substitutes. See U.S. Dep't of Justice, Merger Guidelines, 49 Fed. Reg. 26,823, 26,828 (1984) [hereinafter cited as "Guidelines"] ("The Department will first determine the relevant product market with respect to each of the products of each of the merging firms."). For a general discussion of antitrust market definition, see R. POSNER \& F. EASTERBROOK, ANTrTRUST 347-85 (2d ed. 1981).

2. "Tied products" are those which sellers require to be purchased together. In cluster cases, defendant firms offer to sell a number of "untied products," but do not require that they be purchased together. See R. POSNER \& F. EASTERBROOK, supra note 1, at 802 (discussing tying arrangements).

3. This point was explicitly made by the court in JBL Enter. v. Jhirmack Enter., 509 F. Supp. 357, 368-69 (N.D. Cal. 1981), affd, 698 F.2d 1011 (9th Cir. 1983) (full-line cluster of beauty products held to be relevant market even though individual products were "not interchangeable for the end user" and there was no production flexibility). See also United States v. A.T.\&T., 524 F. Supp. 1336, 1375 (D.D.C. 1981) ("II]n United States v. Grinnell [384 U.S. 563 (1966)] the Supreme Court aggregated central fire alarm and burglar alarm systems without suggesting that these services are economic substitutes to any extent.").

Some courts, however, seem to have clustered products on the basis of supply substitutability. For example, in United States v. Hughes Tool Co., 415 F. Supp. 637 (C.D. Cal. 1976) (clustering specialized surface rotary drilling products), while the court did not explicitly define the market on the basis of supply substitutability, it found that "any large heavy machinery manufacturer would have plant facilities, personnel and at least basic equipment to go into production on any of these products . . within a relatively short period of time." Id. at 642 . This description fits the classic definition of supply substitutability. See R. POSNER \& F. EASTERBROOK, supra note 1, at 352 . See also FTC v. 
of a theoretical framework. Courts have not clearly articulated the circumstances in which nonsubstitutes should be included in the same market. ${ }^{4}$ Instead of invoking substantive standards, courts have often justified cluster definitions merely by relying on such undefined phrases as trade, commercial or economic "reality." To the extent that courts have proposed any substantive criteria, they have failed to explain how or why their chosen standards form a legitimate basis for market definition.

By analyzing the market conditions that cause firms to supply multiple products, this Note seeks to articulate a rational criterion for clustering. In particular, this Note suggests that courts should only cluster together "transactional complements." Goods are transactional complements if buying them from a single firm significantly reduces consumers' transaction costs. Transactional complementarity effectively ties consumer

Lancaster Colony Corp., 434 F. Supp. 1088, 1093 (S.D.N.Y. 1977) (machine-pressed and machineblown soda-lime glassware clustered in part because "many items can be made through either process"). While supply substitutability is a legitimate criterion for including goods in a market, this Note suggests a separate criterion for market definition.

4. See P. Areeda \& D. Turner, Antitrust Law $\$$ 532c, at 403 (1978) ("There is no clear answer to the question whether it was appropriate [in United States v. Grinnell Corp., 384 U.S. 563 (1966)] to treat the various kinds of property protective services-burglary alarm, fire alarm, etc.-together [as a cluster market] rather than treating them separately."); Reasoner, Turner, Glassman, Collins \& Kaplan, Panel Discussion on Market Definition in Merger and Monopolization Cases: Concepts and Techniques, 49 ANTtrRust L.J. 1167, 1179 (1982) (The "concept lof cluster markets] has expanded in the last few years, willy-nilly and without a great deal of analysis."); Rosenthal, Continental Can Revisited: Limits Upon the Breadth of a Line of Commerce in a Section 7 Case, 14 Hous. L. REv. 973, 1010 (1977) ("Although this term [cluster market] has been used on a number of occasions, there is no clearly established standard designating what constitutes a cluster of products.").

5. See United States v. Phillipsburg Nat'l Bank, 399 U.S. 350, 360 (1970) ("trade reality makes commercial banking a distinct line of commerce"); United States v. Grinnell Corp., 384 U.S. 563, 572 (1966) (cluster "reflects commercial realities"); United States v. Philadelphia Nat'l Bank, 374 U.S. 321, 357 (1963) (cluster "meaningful in terms of trade realities"); United States v. Tracinda Inv. Corp., 477 F. Supp. 1093, 1104 (C.D. Cal. 1979) ("commercial realities" do not support motion picture production/distribution cluster); Science Prods. Co. v. Chevron Chem. Co., 384 F. Supp. 793, 797 (N.D. Ill. 1974) ("'R]elevant product market can include clusters . . . where that combination reflects commercial realities."); In re Tenneco, Inc., 98 F.T.C. 464, 568 (1981) ("technical or commercial realities permit" clustering); In re British Oxygen Co., 86 F.T.C. 1241, 1311 (1975) ("trade reality" justifies cluster).

One must be similarly skeptical when courts base cluster definitions on industry and consumer recognition. Just as courts" undefined invocation of "economic reality" does not provide a substantive guideline for clustering, it is unclear which specific industry and consumer recognitions justify clustering. See, e.g., United States v. A.T.\&T., 524 F. Supp. 1336, 1376 (D.D.C. 1981) (industry recognition justifies cluster); FTC v. Lancaster Colony Corp., 434 F. Supp. 1088, 1093 (S.D.N.Y. 1977) (same); United States v. Hughes Tool Co., 415 F. Supp. 637, 640 (C.D. Cal. 1976) (cluster justified in part by "industry usage and recognition"); Science Prods. Co. v. Chevron Chem. Co., 384 F. Supp. 793, 796 (N.D. Ill. 1974) (analyzing industry and public recognition); United States v. Tidewater Marine Serv., 284 F. Supp. 324, 330 (E.D. La. 1968) (industry recognition justifies cluster); In re British Oxygen Co., 86 F.T.C. 1241, 1312 (1975) (same); In re American Medical Int'l, Inc., 3 TRADE REG. REP. (CCH) I 22,170 at 23,040 (F.T.C. 1984) (government and industry recognition justifies health care cluster). 
purchases of multiple products to individual firms and thereby makes the cluster the relevant product. ${ }^{6}$

Part I of this Note describes the varying criteria that courts have used to define cluster markets and concludes that courts have failed to justify coherently the cluster market concept. Part II analyzes the causes of multiproduct supply and presents a theoretical justification for clustering transactional complements. Part III discusses how the suggested transactional complementarity approach should be applied.

\section{Legal Precedent}

A cluster market definition was first adopted in 1963 by the Supreme Court in United States $v$. Philadelphia National Bank: "[T] he cluster of products (various kinds of credit) and services (such as checking accounts and trust administration)' denoted by the term 'commercial bank'... composes a distinct line of commerce."7 The Court defended its definition by arguing that none of the individual products or services of a commercial bank face competition. Rather, distinctiveness, cost advantages or "a settled consumer preference" insulated each commercial banking product from competition with the products of other financial institutions. ${ }^{8}$

The Court's analysis, however, is incomplete. While the Court may have been correct in its determination that the individual products of a commercial bank do not face competition, the Court did not explain why these individual product markets should be grouped together. ${ }^{\circ}$

Three years after Philadelphia National Bank, the Supreme Court in

6. The concept "transactional complementarity" is a new one. However, in showing that the results of neoclassical economic theory change when assumptions are loosened to allow for transaction costs, the approach of this Note parallels that of other recent work. See, e.g., O. WILLIAMSON, MAR-

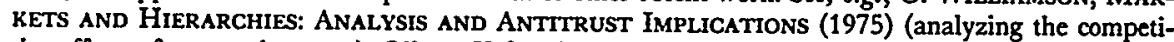
tive effects of transaction costs); Gilson, Value Creation By Business Lawyers: Legal Shills and Asset Pricing, 94 Yale L.J. 239, 253 (1984) (lawyers create value by reducing transaction costs); Harris \& Jorde, Antitrust Market Definition: An Integrated Approach, 72 CALIF. L. Rev. 1, 25 (1984) (criticizing assumptions of neoclassical price theory, suggesting transactional orientation toward market definition).

7. 374 U.S. 321, 356 (1963). Earlier decisions, however, though not using the term "cluster," aggregated non-substitutes into a single market. See, e.g., A.G. Spalding \& Bros. v. FTC, 301 F.2d 585, 603 (3d Cir. 1962) ("athletic goods industry" is appropriate line of commerce); United States v. United Shoe Mach. Corp., 110 F. Supp. 295, 338-39 (D. Mass. 1953) (shoe machines performing 18 different processes aggregated into single market); In re The Papercraft Corp., 78 F.T.C. 1352, 1361-64 (1971) (giftwrap, tying materials and tags included in single market).

8. Philadelphia Nat'l Bank, 374 U.S. at 356-57.

9. Justice Brennan's only justification was that "commercial banking is a market 'sufficiently inclusive to be meaningful in terms of trade realities." Id. at 357 (quoting Crown Zellerbach Corp. v. FTC, 296 F.2d 800, 811 (9th Cir. 1961)).

Since this decision, banking deregulation has increased competition among commercial banks and other financial intermediaries. In United States v. Connecticut Nat'l Bank, 418 U.S. 656, 666 (1974), Justice Powell noted that "[a]t some stage in the development of savings banks it will be unrealistic to distinguish them from commercial banks." 
United States v. Grinnell Corp. ${ }^{10}$ again clustered a group of products. This cluster was comprised of accredited central station services, which included various fire and burglar alarms. ${ }^{11}$ Justice Douglas' opinion went beyond Philadelphia National Bank and suggested that a group of noninterchangeable services should be "lumped" together if "companies recognize that to compete effectively, they must offer all or nearly all types of service."12 Grinnell, then, stands for the proposition that courts should cluster a group of goods when competition causes that group to be supplied together. ${ }^{13}$ The Grinnell Court, however, failed to explain why this standard was appropriate. ${ }^{14}$

The lack of a justifying theory apparent in Philadelphia National Bank and Grinnell has left lower courts virtually unconstrained to develop additional criteria for cluster definitions. Lower courts have based cluster definitions on the existence of trade associations; ${ }^{15}$ census classifications ${ }^{16}$ functional complementarity $;{ }^{17}$ common technology, distribution

10. 384 U.S. 563 (1966).

11. The Court again asserted that viewing a cluster of goods as a single product best captured reality: "We see no barrier to combining in a single market a number of different products or services where that combination reflects commercial realities. To repeat, there is here a single basic service." Id. at 572 .

12. Id. at $\mathbf{5 7 2}$ (footnote omitted). The Grinnell decision implied that service clusters would somehow be judged by a different standard than product clusters: "[W]e deal with services, not with products." Id. The Court did not explain this distinction and, in fact, was forced to mischaracterize the Philadelphia Nat'l Bank definition as a service cluster-even though that decision explicitly defined a loan to be a product. 374 U.S. at 356.

13. In dissent, however, Justice Fortas argued that defendants did not in fact offer "a common or predominant 'cluster' of services." Grinnell, 384 U.S. at 595 (Fortas, J., dissenting).

14. Joint supply may be necessary not only because of transactional complementarity, but also because of economies of scope, see infra Part II.A. Because economies of scope are not an appropriate basis for clustering, see infra text accompanying notes 42 \& 43 , the Grinnell standard is overbroad.

In explaining cluster definitions, several courts have applied standards which, like the overbroad Grinnell standard, may reflect only the presence of economies of scope. For example, courts have clustered products on the basis of trade associations, see infra note 15, and census classifications, see infra note 16. Such characteristics, however, may simply be the byproducts of economies of scope. See Phillips, A Critique of Empirical Studies of the Relation Between Market Structure and Profitability, $24 \mathrm{~J}$. InDUS. ECON. 241, 242, 245 (1976) (census classifications often reflect supply-side linkages). If a group of firms all supply the same set of products, it is not surprising that a trade association or census classification would develop. Even the evolution of names to describe multiple goods (such as "dairy products") may be nothing more than a linguistic artifact of scope economies.

15. See FTG v. Lancaster Colony Corp., 434 F. Supp. 1088, 1092 (S.D.N.Y. 1977); United States v. Times Mirror Co., 274 F. Supp. 606, 617 (C.D. Cal. 1967); In re Brunswick Corp., 94 F.T.C. 1174, 1258 (1979); In re British Oxygen Co., 86 F.T.C. 1241, 1312, 1346 (1975).

16. See United States v. Hughes Tool Co., 415 F. Supp. 637, 641 (C.D. Cal. 1976); In re The Grand Union Co., 102 F.T.C. 812, 1046 n.31 (1983); In re British Oxygen Co., 86 F.T.C. 1241, 1312 (1975).

17. See United States v. Hughes Tool Co., 415 F. Supp. 637, 640 (C.D. Cal. 1976); Science Prods. Co. v. Chevron Chem. Co., 384 F. Supp. 793, 797-98 (N.D. Ill. 1974); In re American Medical Int'l, Inc., TRADE REG. ReP. (CCH) 122,170 , at 23,040 (F.T.C. 1984). But see infra note 22, for discussion of In re British Oxygen Co., 86 F.T.C. 1241, 1359 (1975) (rejecting functional complementarity as cluster basis). 
or marketing, $;^{18}$ a unique product group, ${ }^{18}$ and other market characteristics. ${ }^{20}$ While courts have a plethora of standards from which to choose, they currently have no basis for distinguishing the good from the bad (and the ugly). In sum, while some cluster markets have been defined correctly, ${ }^{21}$ the lack of a sound justifying theory has led courts to adopt conflicting and ad hoc standards. ${ }^{22}$ In a world in which antitrust defendants

18. See United States v. Hughes Tool Co., 415 F. Supp. 637, 641 (C.D. Cal. 1976); In re Tenneco, Inc. 98 F.T.C. 464, 567 (1981); In re Brunswick Corp., 94 F.T.C. 1174, 1258-59 (1979); In re British Oxygen Co., 86 F.T.C. 1241, 1345-47 (1975).

19. See United States v. Household Fin. Corp., 602 F.2d 1255, 1258-60 (7th Cir. 1979); American Medicorp, Inc. v. Humana, Inc., 445 F. Supp. 589, 603-04 (E.D. Pa. 1977); United States v. Healthco, Inc., 387 F. Supp. 258, 265 (S.D.N.Y. 1975); Bowl Am., Inc. v. Fair Lanes, Inc., 299 F. Supp. 1080, 1089 (D. Md. 1969); United States v. Tidewater Marine Serv., Inc., 284 F. Supp. 324, 329-31 (E.D. La. 1968); United States v. Times Mirror Co., 274 F. Supp. 606, 617 (C.D. Cal. 1967); American Medical Int'l, Inc., TRADE REg. REP. (CCH) I 22,170, at 23,040 (F.T.C. 1984).

20. Several cases have defined cluster markets by relying on the "practical indicia" for defining submarkets. These indicia include "industry or public recognition of the submarket as a separate economic entity, the product's peculiar characteristics and uses, unique production facilities, distinct customers, distinct prices, sensitivity to price changes, and specialized vendors." Brown Shoe Co. v. United States, 370 U.S. 294, 325 (1962) (footnote omitted). Decisions which have applied the Brown Shoe submarket criteria as a basis for clustering include: FTC v. Lancaster Colony Corp., 434 F. Supp. 1088, 1092 (S.D.N.Y. 1977); United States v. Healthco, Inc., 387 F. Supp. 258, 264 (S.D.N.Y. 1975); Science Prods. Co. v. Chevron Chem. Co., 384 F. Supp. 793, 795 (N.D. Ill. 1974); Credit Burcau Reports, Inc. v. Retail Credit Co., 358 F. Supp. 780, 789 (S.D. Tex. 1971).

See also United States v. Household Fin. Corp., 602 F.2d 1255, 1260-61 (7th Cir. 1979) ("market segmentation" supports cluster definition); United States v. A.T.\&T., 524 F. Supp. 1336, 1376 (D.D.C. 1981) (cluster market supported by "integrated nature of the telecommunications system"); United States v. Tracinda Inv. Corp., 477 F. Supp. 1093, 1104 (C.D. Cal. 1979) (cannot cluster goods at different levels in "vertical chain"); Science Products Co. v. Chevron Chem. Co., 384 F. Supp. 793, 797 (N.D. Ill. 1974) ("overlap of locus of use" supports cluster definition); Credit Bureau Reports, Inc. v. Retail Credit Co., 358 F. Supp. 780, 790 (S.D. Tex. 1971) ("the degree of differentiation" supports cluster definition); In re American Medical Int'l, Inc., TRADE REG. REP. (CCH) I 22,170 , at 23,040 (F.T.C. 1984) (fact that "almost every [product in cluster] would not exist but for the other[s]" supports cluster definition) (quoting Philadelphia Nat'l Bank, 201 F. Supp. 348, 363 (E.D. Pa. 1962)); In re The Grand Union Co., 102 F.T.C. 812, 1044 (1983) (stronger case for clustering where services are involved, especially "where the services are complex, interrelated, and interdependent"); In re British Oxygen Co., 86 F.T.C. 1241, 1346 (1975) ("synergetic marketing relationship" supports cluster definition).

21. See, e.g., infra text accompanying notes 56,62 \& 63 for a discussion supporting the market definitions in United States v. Philadelphia Nat'l Bank, 374 U.S. 321 (1963) (clustering commercial banking products); JBL Enter., Inc. v. Jhirmack Enter., Inc., 698 F.2d 1011, 1016-17 (9th Cir. 1983) (clustering beauty products); Manufacturing Research Corp. v. Greenlee Tool Co., 693 F.2d 1037, 1043 (11th Cir. 1982) (rejecting conduit and cable bender cluster); In re Brunswick Corp., 94 F.T.C. 1174, 1259 (1979) (clustering marine engines); In re British Oxygen Co., 86 F.T.C. 1241, 1346 (1975) (clustering industrial gases).

22. For example, United States v. Hughes Tool Co., 415 F. Supp. 637 (C.D. Cal. 1976), announced de novo that "complementarity of function" be used as a basis for clustering. Functional complements are those goods "which operate as a group in the performance of [a specific] function." Id. at 640. The Federal Trade Commission, however, had already correctly rejected such a standard in British Oxygen Co.: Functional complementarity "among the products . . does not establish that the products belong in the same economic market. Automobiles need oil and gasoline to be operable, but no one would surely contend that automobiles, oil, and gasoline are all in the same product market." 86 F.T.C. at 1369 (1975). The crucial distinction between functional (or demand) complementarity and transactional complementarity is that consumers can buy the former but not the latter from different producers without incurring significant transaction costs. 
are usually multiproduct firms, ${ }^{23}$ the problem of deciding when to cluster a group of products needs to be formally addressed.

\section{Antitrust ANAIysis of MUltiproduct Firms}

\section{A. The Causes of Multiproduct Firms}

Because clustering only occurs in the multiproduct firm context, articulation of a rational criterion for clustering requires an understanding of the market conditions that cause firms to supply multiple products. In the past, multiproduct production has been explained solely by the concept of economies of scope. ${ }^{24} \mathrm{~A}$ production technology has economies of scope if it is less expensive to produce certain goods together than separately. ${ }^{25}$ The production of wheat and straw, milk and cream, and wool and mutton are classic examples of such scope economies. ${ }^{28}$ By giving multiproduct firms a competitive cost advantage relative to single-product firms, economies of scope encourage firms to supply multiple products. ${ }^{27}$

Multiple product firms, however, may also be the result of transactional complementarity. Goods are transactional complements if buying them from a single firm significantly reduces consumers' transaction costs. In

23. Bailey \& Friedlaender, Market Structure and Multiproduct Industries, 20 J. EcoN. LrTERATURE 1024, 1024 (1982).

24. See W. Baumol, J. Panzar \& R. Willig, Contestable Markets and the Theory of Industry Structure 71 (1982); Panzar \& Willig, Economies of Scope, 71 AM. Econ. Rev. 268, 268 (Papers and Proceedings 1981); Willig, Multiproduct Technology and Market Structure, 69 AM. Econ. Rev. 346, 346 (Papers and Proceedings 1979).

25. See W. Baumol, J. Panzar \& R. Willig, supra note 24, at 72. "Economies of scope" should be distinguished from the better-known concept of "economies of scale." The former results from supplying different products, the latter from supplying more of a single product. See Panzar \& Willig, supra note 24 , at 270 .

26. These examples involve the use of "public inputs" (such as a cow) through which "the production of [beef] necessarily results in the production of [hides] in more or less fixed proportions." $P$. AREeda \& D. TuRner, supra note 4, §521a, at 352. W. BAumol, J. PANZAR \& R. Willig, supra note 24 , at 76 . While such public inputs are sufficient to cause economies of scope, they are not necessary. Rather, they represent a technological extreme-once one good is produced the other is available at little or no cost. Economies of scope will also be present whenever producing one good simply reduces the cost of producing another. For example, once a manufacturer develops sterile facilities for producing one drug, it is likely to be cheaper to produce other drugs as well.

27. Panzar \& Willig, supra note 24 , at 268; Willig, supra note 24 , at 346 . This theory is a natural extension of Coase's prediction that firms will carry out those transactions which they can perform less expensively than can an external market. Coase, The Nature of the Firm, 4 Economica (n.s.) 386,393 (1937).

The tendency of firms to produce supply substitutes is not at odds with the economies of scope theory of multiproduct supply. For example, producing supply substitutes might generate scope economies by allowing firms to react more quickly to arbitrage opportunities. In United States v. A.T.\&T., 524 F. Supp. 1336 (D.D.C. 1981), however, the court erred in inferring supply substitutability from joint supply. The court inferred from "the fact that most firms offering one of the services also offered the other," id. at 1375, "that the degree of cross-elasticity of supply in the industry" was high. Id. at 1375 n.163. See also P. AREedA \& D. Turner, supra note 4, at $\$ 521$ a (mistakenly inferring supply substitutability from joint supply). While supply substitutability may cause economies of scope (and therefore joint supply), the converse need not hold. 
other words, given equal prices, consumers prefer to buy transactional complements from a single firm. ${ }^{28}$ If consumers strongly prefer to purchase a group of goods from a single firm, firms selling only part of this group will not compete effectively with firms supplying the full line. ${ }^{29}$

Transactional complementarity may arise simply from consumers' desire to spread fixed transaction costs among a group of untied products. ${ }^{30}$ If, for example, each trip to a grocery store costs a fixed amount (say, of gas), then, all else equal, consumers will prefer "one-stop shopping"-buying the product group at a single store. ${ }^{31}$

These fixed transaction costs may represent a non-transferable investment that facilitates the purchase of a group of goods from a specific firm. Because such investments may be long-lived, joint purchase need not be simultaneous purchase. For example, a consumer's investment in learning to understand or trust a multiproduct seller could enhance the desirability of the entire product group over a lengthy period. Such firm-specific investments can shift competition among individual products to competition among product clusters. Because both consumers and suppliers realize that purchases of the entire group will effectively be tied to an individual firm once such an investment is made, firms will compete for the investments and the tied sales that such investments imply. ${ }^{\mathbf{3 2}}$

Consumers may also prefer to buy a product group from a single firm if different firms' products are functionally incompatible. ${ }^{33}$ Such interfirm incompatibility reveals the close association between effectively tied transactional complements and explicitly tied goods. To the extent that

28. Formally, joint supply affords the consumer a set of consumption opportunities that "Paretodominates" those opportunities offered by individual producers of the same products. See H. VARIAN, Microeconomic ANalysis 216 (1978) (describing Pareto criterion).

29. The ability of transactional complementarity to cause joint supply was explicitly recognized in In re Brunswick Corp., 94 F.T.C. 1174 (1979). There, the court held that outboard motor dealers, as buyers in the wholesale market, "have strong incentives to display a broad line from a single supplier and, as a result manufacturers have strong incentives to be able to supply that full line." Id. at 1260 (citation omitted).

In fact, demand-side transactional complementarity can even outweigh supply-side diseconomies of scope in determining firm structure. For example, a restaurant might find it cheaper to serve only cold beer or only hot foods (because of thermal externalities), but demand preferences to consume the two together may force joint supply.

30. See Harris \& Jorde, supra note 6, at 25 ("A buyer can spread transaction costs (including search and shopping costs) over a number of different products purchased in a single transaction.").

31. See id. ("A major advantage of supermarkets is that buyers can purchase a bundle of goods on a single trip."). For a discussion of difficulties in defining a grocery cluster, see infra note 62 .

32. See M. Porter, Compettrive Strategy 25 (1980) ("switching costs" may tie demand to individual firms); $O$. WILlIAMSON, supra note 6 , at 48 (firm-specific investments can ex post tie consumers to specific firms); P. Klemperer, Collusion via Switching Costs: How "Frequent-Flyer" Programs, Trading Stamps and Technology Choices Aid Collusion 1-3 (Dec. 1984) (Stanford University unpublished paper) (analyzing switching costs).

33. For example, to the extent that one computer firm's software and peripheral hardware cannot be used with that of other firms, consumers are forced to bring all of their patronage to one firm. 
firms cause this inter-firm incompatibility, they can create transactional complementarity, thereby tying otherwise untied goods. ${ }^{\mathbf{3 4}}$

Transactional complementarity need not be confined to consumer demand. That is, cluster markets may be appropriate not only when firms sell to individuals, but also when firms sell to firms. For example, in In re Brunswick Corp., ${ }^{35}$ the retail dealers of outboard motors preferred to buy a full line of engines from individual manufacturers. In defining an outboard motor cluster, the court held that while "no single consumer has an economic incentive to purchase a number of outboard motors under a single roof rather than shopping around ... dealers have strong incentives to display a broad line from a single supplier."36

Transactional complementarity is thus a demand-side analog to economies of scope, in which the economies accrue to the consumer instead of the producer. For the purpose of market definition, ${ }^{\mathbf{3 7}}$ the crucial distinction between the two concepts is that while transactional complementarity necessitates joint purchase, economies of scope do not necessitate joint sale. $^{38}$ Only transactional complementarity ties consumers' purchases of product groups to individual firms.

34. Klemperer has identified several ways that a firm can penalize consumers who switch companies:

Airlines enroll passengers in 'frequent-flyer' programs that reward them for repeated travel on the same carrier, and some retailers offer trading stamps (Greenshield stamps, S \& H stamps, Pink stamps) which customers can exchange for prizes after sufficiently many have been accumulated from repeated purchases. Auto insurance companies offer 'dividends' that repeat purchasers of insurance can deduct from future premia, and shipping firms have offered 'deferred rebates' that return after a delay a fraction of past payments to customers who continue to patronize them exclusively (though the latter practice is now illegal in the U.S.). Film developing companies often return developed camera film with new film that can be developed only by the same company, and many grocery products are sold with a discount coupon valid for the next purchase of the same item.

P. Klemperer, supra note 32 , at 1 . The similarity of these practices to explicit tying arrangements might suggest their illegality. See R. POSNER \& F. EASTERBROOK, supra note 1, at 802 (discussing tying arrangements).

35. 94 F.T.C. 1174 (1979).

36. Id. at 1259-60. See also Harris \& Jorde, supra note 6, at 25 ("II]ndustrial buyers [may prefer to] purchase a full product line from one supplier, rather than shop for the terms on each single item.").

37. An understanding of the causes of multiproduct firms is necessary not only to define cluster markets correctly, but also to interpret the resulting market shares correctly. For example, both economies of scope and transactional complementarity can, by causing firms in an industry to supply multiple products, create barriers to entry. See J. Bain, BARRIERS to New CoMPETITION 3 (1956) (defining entry barriers to include structural characteristics that may significantly delay entry); but see $G$. StIGLER, The ORganization OF INDUSTRY 67 (1968) (defining entry barriers more narrowly to be a cost borne by an entrant but not borne by an incumbent). For example, transactional complementarity forced manufacturers of outboard motors to produce a full line of engines, see supra note 29 , and thereby greatly increased barriers to entry because potential competitors would have to develop a technologically diverse group of engine sizes in order to enter effectively. For an explanation of how economies of scope can dramatically increase welfare loss associated with even single product collusion, see infra note $\mathbf{4 2 .}$

38. For example, while scope economies dictate that mutton and wool be produced together, there is no requirement that they be sold to the same purchasers. 


\section{Antitrust Gluster Markets}

\section{B. Market Definition in the Multiproduct Firm Context}

Courts should cluster transactional complements into the same market because competition takes place among the effectively tied groups, not the individual products. ${ }^{39}$ Just as products that are explicitly tied together by producers are routinely aggregated into one market, ${ }^{40}$ so should products that are effectively tied together by consumer purchasing behavior. Transactional complementarity makes the market for the cluster of products the relevant market. ${ }^{\text {1 }}$

Economies of scope do not analogously connect goods from the suppliers' perspective. Because economies of scope do not necessitate that goods be sold together, firms can collude on single products profitably. ${ }^{42}$ Thus,

39. See Harris \& Jorde, supra note 6, at 33 ("If buyers typically purchase products in bundles (c.g., groceries), full-line stores may constitute a separate market from specialty stores, especially if there are significant transaction cost savings involved.").

40. For example, the steering wheel and the rest of the car are unavoidably placed in the same market.

41. The cluster seen as a single product would then be subject to the traditional substitutability criterion. See, e.g., United States v. Grinnell Corp., 384 U.S. 563, 573 (1966) (analyzing whether there are "substitutes for the accredited central station" cluster).

This transactional complement approach is not antithetical to the traditional substitutability approach. Transactional complements can be supply substitutes and, as such, can be included in a single market on both grounds independently.

42. Only in the case of joint products (such as beef and hides, discussed supra note 26) would a collusive restriction of one good's output necessitate a restriction of another good's output as well. Because such products are produced in fixed proportions, however, and because the individual and cluster market definitions will thus yield identical market share and concentration measures, the decision whether or not to cluster is unimportant. As mentioned supra note 26, joint products represent a technological extreme. More generally, economies of scope do not necessitate production in fixed proportions.

FIGURE A

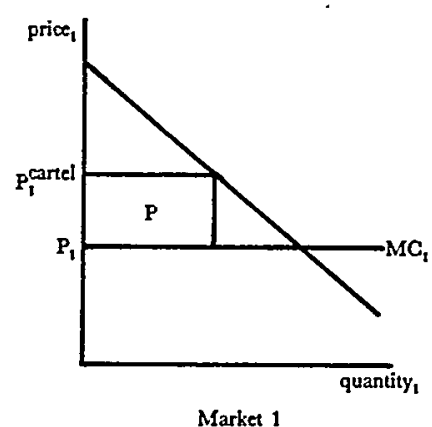

Market 1

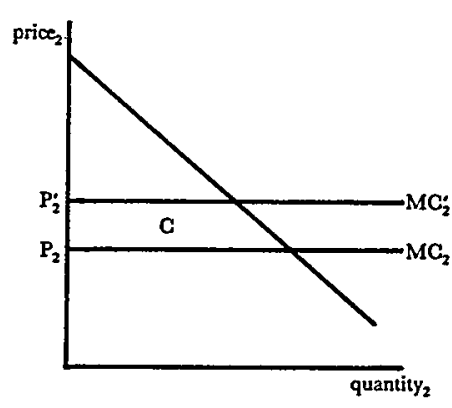

Market 2

$\mathrm{MC}_{1}, \mathrm{MC}_{2}=$ pre-cartel marginal costs in markets 1 and 2

$P_{1}, P_{2} \quad=$ pre-cartel competitive prices in markets 1 and 2

$\mathrm{MC}_{1}, \mathrm{MC}_{2}^{\prime}=$ post-cartel marginal costs in markets 1 and 2

$\mathrm{P}_{1}^{\text {cartel }} \mathrm{P}_{2}^{\mathrm{p}}=$ post-cartel prices in markets 1 and 2 
even though economies of scope cause joint supply, they do not justify clustering. ${ }^{43}$

\section{Harmonizing Cluster Markets with the D.O.J. Guidelines}

The Department of Justice Merger Guidelines include in a market those products whose price a cartel would have to control to obtain monopoly profits. ${ }^{44}$ Although the Guidelines currently define individual markets for each of defendant's products, ${ }^{45}$ the Guidelines' underlying ration-

Economies of scope, however, may dramatically increase the welfare loss associated with single product collusion. Consider, for example, an economies of scope technology in which producing more of a first good reduces a firm's cost of producing a second good. If firms agree to cartelize the first good and restrict its output, then the cost of the second good will rise. Even if the second market remains competitive-in the sense that there are zero profits and marginal cost pricing-there will be a welfare loss in the second market which may dwarf the traditional welfare loss created by the cartelization of the first market. Though producers are just breaking even in the second market, there is significant welfare loss because goods are being produced at an inefficiently high cost. Figure A illustrates that the losses in the second market induced by economies of scope (Area C) may be significantly larger than the traditional dead-weight triangle (Area T).

These additional welfare losses may increase significantly Harberger's calculation that the annual welfare loss in the United States in the 1920's due to monopoly was only two dollars per capita. Harberger, Monopoly and Resource Allocation, 44 AM. EcoN. REv. 77 (1954).

43. This result is contrary to that of Areeda and Turner, who have proposed that:

[P]roducts produced in common facilities ... are in the same market .... This is so whether (1) the products are 'joint products' where the production of $\mathrm{X}$ necessarily results in the production of $\mathrm{Y}$ in more or less fixed proportions, or (2) the facilities are freely convertible from one product to the other.

P. AREedA \& D. TURner, supra note 4 , at $\S 521 \mathrm{a}$. This analysis is flawed because it assumes that joint supply is caused only by joint products or freely convertible facilities. The latter cause (often called supply substitutability), while being an independent ground for market definition, is neither a necessary nor a sufficient cause of joint supply. See supra note 27 . The former, while being a sufficient cause of economies of scope and therefore joint supply, represents a technological exception that will result in identical market shares for the cluster and individual product markets. See supra note 26.

44. This principle of market definition naturally incorporates the traditional process of including substitutes in the relevant market. A cartel which excludes a close substitute could not profitably increase price, because too much of the cartel's demand would shift to the lower-priced substitute.

This restatement differs in form from the Guidelines' wording: "[T]he product market [will include the smallest] group of products such that a hypothetical firm that was the only present and future seller of those products ("monopolists') could profitably impose a 'small but significant and nontransitory' increase in price." Guidelines, supra note 1 , at $\$ 2.11$. Under either formulation the hypothetical cartel controls its price but does not control the price at which other firms sell.

This Note's restatement improves the Guidelines' formulation, because the Guidelines speak of increases beyond the current price. Firms that are already pricing supra-competitively will be placed incorrectly in larger markets. For example, because an existing monopolist cannot profitably increase price, under the Guidelines' formulation, it would be placed incorrectly in a larger market. See Note, The Cellophane Fallacy and the Justice Department's Guidelines for Horizontal Mergers, 94 YaLE L.J. 670, 676-77 (1985) (criticizing application of Guidelines' approach to supra-competitive prices). The Guidelines' method is also inadequate because it does not allow firms outside the market to react (usually by raising their own price) to the hypothesized price increase. This flaw will tend to define markets too broadly and thus dilute the merging firms' market shares.

45. Guidelines, supra note 1 , at $\S 2.11$. The Guidelines' procedure for defining markets is derived from Kenneth Boyer's innovative concept of an "ideal collusive group." Boyer, Industry Boundaries, in Economic ANALYSis and ANTITRUST Law 88 (T. Galvani \& J. Seigfried eds. 1979). 
ale lends independent support for the clustering of transactional complements.

When consumers' purchases are effectively tied to individual cluster producers, the consumers will choose on the basis of a set of prices. A cartel that does not reach agreement with regard to all prices within the cluster cannot profitably collude, because firms will have an incentive to lower the price of the non-collusive goods to attract more sales. ${ }^{48}$ Controlling the price of all the cluster goods, even when the goods are untied, is therefore necessary for profitable collusion. ${ }^{47}$

The Guidelines' rationale also makes clear that economies of scope are not an appropriate basis for clustering, because manufacturers need not control the price of more than one product in order to collude profitably. ${ }^{48}$

\section{Applying the Transactional Complementarity Approach}

Defining clusters on the basis of transactional complementarity secures market definition in a coherent theory. Furthermore, it focuses judicial attention on well-specified factual questions that courts are competent to address and have, in fact, answered in the past. This Part suggests guidelines for determining when transactional complementarity is present and for handling firms that supply only part of the cluster product group. It then analyzes the various incentives that encourage antitrust litigants to propose cluster definitions.

46. Any effective cartel must prohibit the explicit tying of below-cost goods. For example, a profitable theater cartel could not allow one of its members to give away light bulbs with every ticket purchase, because tying the light bulb giveaway to the purchase of tickets would induce consumers to purchase more tickets from the giveaway theater. A transactional complements cartel, however, must in addition prohibit even untied below-cost sales in order to collude profitably, because merely offering below-cost transactional complements can induce consumers to purchase the entire cluster.

47. Transactional complementarity thus increases the dimensionality of necessary agreement, because a profitable cartel must reach, monitor and enforce an agreement concerning the entire cluster. This increased dimensionality may discourage collusive agreements because firms must negotiate many collusive prices instead of only one. The need for more involved negotiations, by itself, would tend to inhibit collusion. However, cartel members may be able to decrease this dimensionality by agreeing to a uniform mark-up (also called "administered pricing") or agreeing to fix a market-basket price.

48. The industrial organization literature has long recognized that firms may successfully agree to restrict price competition without necessarily agreeing to restrict areas of non-price competition such as advertising. The fact that competition over some products cannot eliminate the profits of collusion over others parallels Schmalensee's finding that advertising competition will not eliminate price collusion. Schmalensee, A Model of Advertising and Product Quality, 86 J. PoL. Econ. 485, 498-99 (1978). In both instances the dimensionality of necessary agreement does not increase. In contrast, the dimensionality of necessary agreement does increase when there are significant transactional complementarities. See supra note 47. 


\section{A. Establishing Transactional Complementarity}

To establish the existence of transactional complementarity, courts should investigate consumer behavior to see whether consumers' purchases of a product group are tied to individual firms. ${ }^{49}$ Specifically, courts should ask whether consumers buy the group of goods from individual firms. Moreover, because transactional complementarity leads consumers to compare prices of the entire cluster instead of individual goods, evidence that manufacturers promote their goods on the basis of joint price indices would be evidence of transactional complementarity. ${ }^{50}$

Transactional complementarity analysis provides a clearer justification for the Court's commercial banking cluster definition in United States $v$. Philadelphia National Bank. ${ }^{51}$ By limiting itself to a product-by-product analysis, the Supreme Court could not explain the "settled consumer preference" for commercial banks' savings accounts which, but for paying a lower return, were identical to those offered at savings and loans. ${ }^{62}$ The opinion quoted a bank official: "[T]here isn't anybody in Philadelphia who will take the trouble to walk across Broad Street to get $1 / 2$ of 1 per cent more interest. If you ask me why, I will say I do not know."ss Transactional complementarity analysis explains that this settled consumer preference was not for savings accounts alone, but for the group of services as a whole offered by commercial banks.

Indeed, the Supreme Court has already relied upon this factual finding. For example, in United States v. Phillipsburg National Bank, ${ }^{\text {s4 }}$ the Supreme Court relied explicitly on a finding that consumers preferred purchasing multiple products from individual commercial banks to support a cluster definition: "A customer who uses one service usually looks to his bank for others as well ... . [G]ustomers are likely to maintain checking and savings accounts in the same local bank even when higher

49. By focusing on consumer behavior, courts would be examining the effects of transactional complementarity. Courts could also weigh evidence of the causes of transactional complementarity-for example, whether consumers significantly save time or money by buying the group of products from an individual store. Ascertaining information about consumers' preferences, however, is likely to be more difficult than analyzing actual consumer behavior. See Harris \& Jorde, supra note 6, at 29-31 (transactional approach to market definition should be based on observable consumer behavior).

50. For example, grocery stores sometimes advertise that they offer the lowest weekly food bill.

51. 374 U.S. 321 (1963).

52. The fact that savings accounts at savings and loans are identical but still excluded from the market demonstrates that the market was not defined on the basis of supply-side substitutability.

53. Philadelphia Nat'l Bank, 374 U.S. at 357, n.34.

54. 399 U.S. 350 (1970). 


\author{
savings interest is available elsewhere." In ${ }^{285}$ essence, this is a finding of \\ transactional complementarity. ${ }^{\text {se }}$
}

\title{
B. Analyzing Partial Cluster Producers
}

The existence of partial cluster producers-firms that produce only a subset of the products in the cluster group ${ }^{6 z}$ - demonstrates that at least some consumers (at least one demand segment) ${ }^{58}$ do not consider the prod-

55. Id. at 361. Phillipsburg Nat'l Bank also goes beyond Philadelphia Nat'l Bank in describing the source of this consumer preference. By offering various services together, commercial banks reduce consumers' transaction costs not only by facilitating "convenient access" but also by inexpensively establishing consumers' credit ratings. By establishing checking or savings accounts, a consumer can convey information about her credit worthiness and thus facilitate obtaining a loan. Phillipsburg Nat'l Bank explicitly echoed this theory by finding that the consumer "who has patronized a particular bank for a variety of financial products and services is more likely to be able to obtain a loan from that bank than from a specialty financial institution to which he turns simply to borrow money." Id. at 360-61. Philadelphia Nat'l Bank was similarly construed by JBL Enter. v. Jhirmack Enter., 698 F.2d 1011 (9th Cir. 1983): "[C]onsumers do not generally shop for individual banking services, especially because it is usually easier to obtain some services, e.g., loans, at the same bank where other services, e.g., savings accounts, are held." Id. at 1017.

If establishing a savings account makes it easier to obtain loans, consumers may be willing to forego a higher yield. As long as there is a chance that consumers will need loans in the future, there will be a real option value associated with establishing a savings account at a commercial bank. The value of this option to borrow at a commercial bank will be higher 1) the more likely it is that a consumer will need to borrow and 2) the more that an established savings account facilitates obtaining a loan (the greater the transaction cost savings). This option value theory not only solves the Philadelphia Nat'l Bank conundrum of a consumer preference for inferior-yielding savings accounts but also suggests an additional source of transactional complementarity. See Henry, Option Values in the Economics of Irreplaceable Assets, 89 REV. EcoN. STUD. 104 (1974) (using similar model to evaluate option value).

56. Analysis close to the transactional complements approach has been used in four cases. In Manufacturing Research Corp. v. Greenlee Tool Co., 693 F.2d 1037, 1043 (11th Cir. 1982), the court, in rejecting a cluster of conduit and cable benders, distinguished both Grinnell and Philadelphia Nat'l Bank, because in those cases "[d]ifferent services were lumped together . . only because demand forced competitors to offer the entire cluster of services as effectively one product" (emphasis added). The Greenlee statement correctly goes beyond the Phillipsburg finding by making demandforced joint supply the only reason for clustering.

Like Phillipsburg, three F.T.C. decisions have cited a consumer preference for joint purchase as a contributing factor in clustering. In re Brunswick Corp., 94 F.T.C. 1174, 1259 (1979) (marine engine cluster justified in part because "dealers prefer a full line, usually sourced by a single brand"); In re British Oxygen Co., 86 F.T.C. 1241, 1346 (1975) (industrial gases cluster justified in part "because many buyers prefer to order [a full line of gases] from one gases supplier"); In re The Grand Union Co., 102 F.T.C. 812, 1045 (1983) (supermarket cluster justified in part because "'one-stop shopping' . . is preferred by many consumers"). See also JBL Enter. v. Jhirmack Enter., 698 F.2d 1011, 1016-17 (9th Cir. 1983) ("cluster approach is appropriate where the product package is significantly different from, and appeals to buyers on a different basis from, the individual products considered separately").

57. A basic requirement of a cluster theory is to explain the existence of partial cluster producers. It is insufficient to say, as in United States v. Grinnell Corp., 384 U.S. 563, 574 (1966), that watchman service does not compete with electronic burglar alarms because it "is far more costly and less reliable." If this were universally the case, no one would hire watchmen. Similarly, in Philadelphia Nat'l Bank, small finance companies were found not to compete with commercial banks because they were more costly. This theory, however, does not explain why small finance companies have continued to exist. Finance companies could still compete with higher prices if consumers had to make reputational investments to obtain loans from commercial banks. See supra note 55.

58. In attempting to establish whether transactional complementarity is present, courts may find 
ucts to be transactional complements. ${ }^{5 \theta}$ Nevertheless, as long as a court finds that a significant group of consumers ${ }^{60}$ considers a product group to be transactional complements, a cluster definition is appropriate. ${ }^{61}$ Such cluster definitions should exclude partial cluster producers. The partial cluster producers cannot compete for sales to those consumers with a transactional complement preference, because, by definition, individual products do not appeal to these consumers.

This analysis provides a theoretical justification for excluding savings accounts at savings and loans from the commercial banking cluster in United States $v$. Philadelphia National Bank. ${ }^{62}$ Savings and loans can be viewed as partial cluster producers, because they provide only one of the services-savings accounts-that make up the commercial banking cluster.

that some consumers view the members of the product group as transactional complements, while others treat them independently. To distinguish such preferences courts must define demand segments. While complicating the analysis, demand segment definition is not unworkable and, in fact, has already been attempted by courts. See, e.g., United States v. Household Fin. Corp., 602 F.2d 1255, 1260-61 (7th Cir. 1979) ("market segmentation" supports cluster definition). Procedures for defining market segments have also been set forth in the marketing literature. See, e.g., Blattberg \& Sen, Market Segmentation Using Models of Multidimensional Purchasing Behavior, $38 \mathrm{~J}$. MARKETING 17, 19 (1974).

59. If all consumers preferred to purchase a product group from individual firms, partial cluster producers would be at a severe competitive disadvantage and would not survive in the long run.

60. While the term "significant" is somewhat vague, courts have confidently applied it in antitrust analysis to avoid de minimis problems. See, e.g., United States v. Household Fin. Corp., 602 F.2d 1255, 1258 (7th Cir. 1979) (cluster must be offered to "significant number of consumers" to be appropriate); International Salt Co. v. United States, 332 U.S. 392, 396 (1947) ("unreasonable, per se, to foreclose competitors from any substantial market").

61. Similarly, other commentators have suggested that markets be defined with respect to particular demand segments. See Harris \& Jorde, supra note 6, at 18 ("market definition should begin from the perspective of the injured . . . buyer or seller group"); Note, The Line of Commerce for Commercial Bank Mergers: A Product-Oriented Redefinition, 96 HARv. L. REv. 907, 919 (1983) (market definitions should begin by identifying "customer segments").

Clustering despite the existence of partial cluster producers is also supported by the Guidelines' rationale for market definition. See supra note 44 and accompanying text. By the Guidelines' rationale, the presence of partial cluster producers does not invalidate a cluster definition if a cluster cartel could profitably collude. The existence of these partial cluster producers need not eliminate the possibility of a profitable cluster carrel, because that cartel could simply cede the non-cluster demand segments to the partial cluster firms. Moreover, the cluster cartel might compete with partial cluster producers by charging a competitive price on overlapping goods, and still extract collusive profits by only raising the price of the non-overlapping products.

62. 374 U.S. 321 (1963). This analysis is at odds, however, with the FTC's inclusion of "limited assortment" warehouse stores (which only sell non-perishable groceries) into a full-line grocery store cluster in In re The Grand Union Co., 102 F.T.C. 812, 1045 (1983). In that case, Chairman Miller reasoned that a "substantial segment of consumers . . ., even if disinclined to make multiple shopping trips, may nevertheless purchase the more durable food products, from, say, box or warehouse stores in one week, and follow the next week patronizing a supermarket with the full 'cluster' of services." $I d$. Such consumer behavior, however, does not justify including the non-perishable sales of the warehouse store in the relevant market, because full-line grocery stores could continue to collude profitably even if the warehouse stores priced the non-perishables competitively. The full-line grocery stores . could cede the non-perishable food sales to the warehouses stores every few weeks and still profitably collude during the times when consumers prefer "one-stop shopping." Moreover, a full-line cartel might not even need to cede the non-perishable sales, because it could price non-perishables competitively with the warehouses and extract the monopoly rents through the nondurable prices. 
Although the existence of savings accounts at savings and loans indicates that some consumers purchased this service independently, the fact that a substantial number of other consumers preferred to hold savings accounts at commercial banks, even though these accounts yielded less, demonstrates that cluster producers had the power to raise price profitably. ${ }^{63}$ Such savings accounts were thus properly excluded from the cluster definition.

\section{Analyzing Adversarial Incentives}

In deciding whether or not to cluster a group of products, a court will face one of two adversarial positions-either plaintiff or defendant will favor clustering while the opposing party will favor individual product definitions. ${ }^{64}$ Regardless of competitive realities, adversaries will propose the market definitions that most favor their position. An analysis of the adversarial incentives should inform a court's clustering decision.

An adversarial position in which defendants seek individual market definitions requires transactional complementarity analysis because defendants' incentives to oppose a cluster definition may be proper. ${ }^{65}$ First, because a cluster market share is an average of individual market shares, ${ }^{68}$

63. The amount of collusion will be limited by the degree to which goods are transactional complements. If consumers have only a weak preference for joint purchase, supra-competitive prices by cluster producers will cause consumers to buy the products independently.

64. More generally, the litigants might disagree about the appropriate size of the cluster. See, e.g., United States v. Hughes Tool Co., 415 F. Supp. 637, 641 (C.D. Cal. 1976) (rejecting plaintiff's 16product cluster in favor of defendant's 36-product cluster). For the purposes of this section, the side seeking the smaller cluster is analytically similar to a party seeking individual product definitions.

65. In the majority of cases, plaintiffs have been the parties seeking a cluster definition. See, e.g., United States v. Grinnell Corp., 384 U.S. 563, 571-72 (1966); United States v. Philadelphia Nat'l Bank, 374 U.S. 32, 356 (1963).

66. As with market shares, clustering will generally dampen the Herfindahl-Hirschman index of concentration (HHI). The HHI is defined as the sum of the squares of the market shares of all firms in the industry. The effect of clustering on the HHI is important because the Guidelines, supra note 1 , at $\S 3.1$, rely on the $H H I$ and the difference between pre- and post-merger $H H I s(\Delta H H I)$ to determine whether a merger is likely to have anticompetitive effects.

The HHI under a cluster definition must be below that of at least one of the individual products. In fact, the HHI may fall below that of the least concentrated product market. For example, in Table 1 the HHI for products A and B is each 4200 , while the HHI for the cluster of A and B is only 3750.

TABLE 1

MARKET SHARES

PRODUCT A PRODUCT B PRODUCT CLUSTER

$\begin{array}{llll}\text { FIRM 1 } & 50 & 50 & 50 \\ \text { FIRM } 2 & 10 & 40 & 25 \\ \text { FIRM 3 } & 40 & 10 & 25\end{array}$

The dampening effect of clustering on concentration measures, however, is not absolute. In merger cases the $\Delta \mathrm{HHI}$ need only be greater than the smallest increase of the individual product markets and may be greater than even the largest $\Delta H H I$ of any individual market. For example, in Table 1 , if the second and third firms merged, the $\Delta H H I$ for products $A$ or $B$ would be 800 , while the $\Delta H H I$ for the 
clustering a market in which a defendant has a high market share with a market in which the defendant has a low market share can extend antitrust liability to markets in which it is not justified. ${ }^{67}$

Second, plaintiffs may seek a cluster definition to gerrymander not only market shares but also evidence of anticompetitive conduct. For example, in United States v. A.T.\&T. ${ }^{68}$ defendants claimed that the government's proposed cluster definition improperly joined markets "in which their market share [was] high but for which the government did not prove significant anticompetitive conduct, together with those for which improper conduct may have been proven but in which their market share [was] relatively low." ${ }^{\prime 68}$ Such aggregation may unfairly create antitrust liability by locating the necessary elements of an offense in independently lawful markets.

Finally, plaintiffs may unjustly propose a cluster market to exclude from the market definition partial cluster producers that are, in fact, competing with the defendant's individual products. Such inappropriate exclusion of partial cluster producers can overstate dramatically a defendant's market share.

In the contrasting adversarial position, however, defendants do not have legitimate reasons to seek cluster market definitions. In fact, defendants will have incentives to seek cluster definitions only when individual market definitions are appropriate. A defendant will only seek to cluster when the cluster market share, as an average of the individual market shares, is so reduced as to enable the defendant to avoid or lessen liability. For example, a defendant might prefer a cluster definition to individual market definitions if its market shares for products $\mathrm{A}$ and $\mathrm{B}$ were fifty and ten percent, respectively. The cluster share of thirty percent might avoid liability while the fifty percent share for product $\mathrm{A}$ could be violative.

Such a difference in the market shares of the individual products is itself strong evidence that a significant group of consumers does not con-

cluster would be 1250 . This "overstatcment" of the cluster $\Delta H H I$ is, however, somewhat pathological as it will only occur if the pre-merger cluster $\mathrm{HHI}$ is less than each of the individual products.

67. For example, if a defendant has a 90 percent share in one product market and 10 percent share in another, a plaintiff may wish to cluster so that the resulting 50 percent cluster market share will extend antitrust liability to the second market.

Inappropriate clustering can increase the size of either divestiture remedies or monetary damages. In forming divestiture remedies, courts should adopt a conservative posture. Even if a court errs and only divests single products when cluster divestiture is appropriate, the defendant will be forced to divest both products. Because transactional complementarity encourages joint supply, the single product entity would be less marketable.

68. 524 F. Supp. 1336 (D.D.C. 1981).

69. Id. at 1375. Although the court upheld the cluster definition on the facts, it recognized that such gerrymandering could occur: "If aggregating markets leads to the appearance of a causal link between defendants' anticompetitive conduct and their monopoly power which disappears the moment the markets are treated separately, then clearly the aggregation would be improper." Id. at 1376. 
sider the products to be transactional complements. ${ }^{70}$ The existence of significant demand segments that do not consider product groups to be transactional complements makes individual market definitions at least a plausible alternative to a cluster definition. ${ }^{71}$ Under these circumstances, however, if a plaintiff can point to an anticompetitive situation in one relevant market, it should not be a defense to claim that there is competition in another. Therefore, courts should not allow defendants to interpose a cluster definition as a defense. ${ }^{72}$

Such a prohibition of defensive clustering found acceptance in Hittman Nuclear \& Development Corp. v. Chem-Nuclear Systems, Inc. ${ }^{73}$ The court, in rejecting the defendant's cluster definiton, held that Grinnell and Philadelphia National Bank "certainly provide no authority for combining two or more distinct markets into one larger market so that a defendant may avoid antitrust liability."

\section{CONCLUSION}

To correctly define cluster markets courts must understand why firms supply multiple products. This Note has introduced the term "transactional complementarity" to further this understanding. Transactional complementarity, like economies of scope, can cause multiproduct firms. But unlike economies of scope, only transactional complementarity can tie consumers' purchases of different goods to individual firms. ${ }^{75}$ Transactional complements should be clustered because competition takes place among the effectively tied groups and not the individual products. In our economy dominated by multiproduct firms, antitrust law needs to develop a coherent theory of cluster markets. The current failure to recognize the relevance of transactional complementarity is a serious judicial flaw.

70. If a defendant has $50 \%$ of one market and only $10 \%$ of another, there are likely to be some purchasers of the first product who are not purchasers of the second, and who do not consider the second to be a transactional complement.

71. An individual product cartel could collude and extract monopoly profits from those consumers who purchase goods independently. There can thus arise instances in which individual as well as cluster markets can be relevant lines of commerce. For example, in In re The Grand Union Co., 102 F.T.C. 812, 1046 (1983), the defendant full-line grocery might have the opportunity to participate in either a non-perishables cartel or a full-line cartel. For a more complete discussion of this case, see supra note 62 .

72. Defendants, however, should still be able to contest the plaintiff's exclusion of rivals' individual products as non-substitutes.

73. 1980-1 Trade CAS. (CCH) II 63,140, at 77,682 (D. Md. 1979).

74. Id. at 77,682. But see JBL Enter. v. Jhirmack Enter., 698 F.2d 1011, 1016 (9th Cir. 1983) (rejecting plaintiff's shampoo market in favor of defendant's beauty-products cluster); United States v. Hughes Tool Co., 415 F. Supp. 637, 641 (C.D. Cal. 1976) (rejecting plaintiff's 16-product cluster in favor of defendant's 36-product cluster).

75. While this Note has examined the theory of transactional complimentarity, future empirical work should document the prevalence of transactional complimentarity and the degree to which it is responsible for altering consumer behavior and determining industry structure. 